\title{
Population dynamics of Triatoma vitticeps (Stål, 1859) in Itanhomi, Minas Gerais, Brazil
}

\author{
Rita de Cássia Moreira de Souza, Silvia Ermelinda Barbosa, Ivan Vieira Sonoda, \\ Bernardino Vaz de Melo Azeredo', Álvaro Jose Romanha², Liléia Diotaiuti/+
}

Laboratório de Triatomíneos e Epidemiologia da Doença de Chagas ${ }^{2}$ Laboratório de Parasitologia Celular e Molecular, Instituto René Rachou-Fiocruz, Av. Augusto de Lima 1715, 30190-002 Belo Horizonte, MG, Brasil 'Secretaria de Estado da Saúde de Minas Gerais, Belo Horizonte, MG, Brasil

Taxonomic markers (head structure morphometry, isoenzymes and randon amplified polymorphism of DNA $R A P D)$ were used to understand the population dynamics of Triatoma vitticeps, predominant triatomine species in Itanhomi district, using samples obtained from domestic, peridomiciliary and sylvatic habitats. Morphometric analysis revealed sexual dimorphism within the three samples although specimens could not be separated according to the habitat in which they were captured. Forty-two bands were analyzed from RAPD profiles generated using four primers. A dendrogram constructed from Dice's similarity coefficient values showed that migration of the insects between the habitats has occurred, without structuring of populations. Moreover, the dendrogram obtained from the genetic distance values showed an important gene flow between the sylvatic and domestic habitats. No polymorphism was found in the electrophoretic mobility of proteins for the ten enzymes studied. Our results revealed movement of triatomines between the three habitats, suggesting that the presence of T. vitticeps in houses should not be ignored. As invasion of houses by sylvatic insects is frequent and the natural infection indices of this species are among the highest known, epidemiological vigilance studies may reveal possible changes in $\mathrm{T}$. vitticeps behaviour which could present future risks to public health.

Key words: Triatoma vitticeps - isoenzymes - head morphometry - RAPD - population dynamics

The reduviid bug Triatoma vitticeps (Stål 1859) is one of 141 species of Triatominae (Galvão et al. 2003, Galvão \& Angulo 2006, Costa et al. 2006, Costa \& Felix 2007, Sandoval et al. 2007, Bérenger \& Blanchet 2007, Martinez et al. 2007) and is a vector of Trypanosoma cru$z i$. Its geographical distribution is limited to the Brazilian states of Bahia, Espírito Santo, Minas Gerais (MG), and Rio de Janeiro (Galvão et al. 2003). Although considered to be of secondary importance in T. cruzi transmission to man, this species shows high rates of trypanosome infection (Santos et al. 1969a,c, Pinto et al. 1969, 1986, Barros et al. 1975, Sessa \& Carias 1986, Dias et al. 1989, Gonçalves et al. 1998, Santos et al. 2005) and is often captured in man-made habitats, with frequent reports of adult bugs invading houses (Santos et al. 1969b, Ferreira et al. 1986, Sessa \& Carias 1986, Dias et al. 1989, Gonçalves et al. 1998), possibly attracted by light (Ferreira et al. 1986).

The Itanhomi district is situated in the Rio Doce valley. Lying within an area originally occupied by the Atlantic Forest, it has a humid climate and mountainous terrain. According to technical reports of the Brazilian Health Service (FUNASA) published between 1990-1999, T. vitticeps is the predominant triatomine species collected in this area, and its infection rates by flagellates similar

+Corresponding author: diotaiuti@cpqrr.fiocruz.br

Received 16 February 2007

Accepted 12 February 2008 to $T$. cruzi are very high, especially in adult bugs captured indoors in Itahomi. However, Chagas disease is rare in the area, a prevalence of only $0.4 \%$ has been recorded as part of a national serological survey (Camargo et al. 1984). It is not known whether the low transmission of T. cruzi to man is due to characteristics of the vector (the long interval between feeding and defecation) or the strain of parasite involved.

Among the available taxonomic marker techniques, morphometry of the head, random amplified polymorphism of DNA (RAPD) and isoenzyme analysis have been most used in triatomine population studies (Costa et al. 1997, Dujardin et al. 1998, Borges et al. 2000, Soares et al. 2001, Barbosa et al 2003, 2006). We used these three techniques to investigate $T$. vitticeps population dynamics in the Itanhomi district.

\section{MATERIALS AND METHODS}

Study area - Itanhomi (19 $\left.11^{\prime} 15^{\prime \prime} \mathrm{S}, 41^{\circ} 48^{\prime} 45^{\prime \prime} \mathrm{W}\right)$ has an estimated population of 11,012 inhabitants. The urban and rural area comprise 93 localities. In 11 of the rural sites (Adão Daniel, Cabeceira do Guido, Francisco Inácio, Jesus Julião, Jose Horta, Jose Noberto, João Caboclo, Júlio Carlos, Liés Alves, Orides I, and Valico) the search for T. vitticeps was intensively performed in 2002 in domestic and peridomestic environments. The following year, sylvatic sampling was attempted in Cabeceira do Guido, particularly in a wooded area $100 \mathrm{~m}$ from a house where adult triatomines are periodically detected.

Houses in Itanhomi in which $T$. vitticeps was sampled conform to a distinct pattern of construction, being built on stilts. The floors of these dwellings are wooden 
and often have cracks that allow triatomines to pass in and out; the floor is a kind of roof for the open basement (classified as the peridomicile). Houses are built on stilt, providing shelter for domestic animals and storage of materials. Furthermore, $100-500 \mathrm{~m}$ from the houses there are remnants of Atlantic forest and rocks, constituting sylvatic habitat for the bugs. This peculiar characteristic of the locality is the proximity of the habitats.

Insects - A pool of T. vitticeps captured in Itanhomi was studied, consisting of species caught at intradomiciliary, peridomiciliary (around and under the stilt of houses), and sylvatic habitats. The $T$. vitticeps infestation rate was calculated based on manual collection in 256 houses (33 triatomines), and their respective outbuildings (16 insects). Thirty houses (11.7\%) and six outbuildings (2.3\%) were positive for this species. With respect to sylvatic captures, seven insects were collected in two light traps hung from 18:00-21:00 $\mathrm{h}$ on three consecutive nights near a house that was regularly invaded by triatomines in Cabeceira do Guido. Each trap consisted of a white sheet $2.5 \mathrm{~m}$ long by $1.5 \mathrm{~m}$ high, hung vertically $80 \mathrm{~cm}$ above the ground, with a $250 \mathrm{~W}$ white fluorescent lamp positioned centrally behind it. The insects were transported to the laboratory, maintained under controlled conditions of temperature $\left(27 \pm 2^{\circ} \mathrm{C}\right)$ and relative humidity $(60 \pm$ $10 \%$ ), and weekly fed on chickens. All the females were fertile and laid eggs. Adult insects of the first laboratory generation were used to perform the experiments.

Morphometry - A series of six measurements of the head of 15 males and 15 females from each habitat were taken (Fig. 1), as recommended by Dujardin et al. (1998). The measurements were made using the KS/300 computerized image analysis system, with a Carl Zeiss KONTRON Electronic GMBH model at a magnification of 30x. The values obtained were transformed into natural logarithms and submitted to uni- and multivariate analyses. Univariate analysis was performed by calculating Guillaumin profiles (Guillaumin 1972), calculated from the difference between the group and overall means for each variable, divided by the standard deviation showing the relationships of size among the vari-

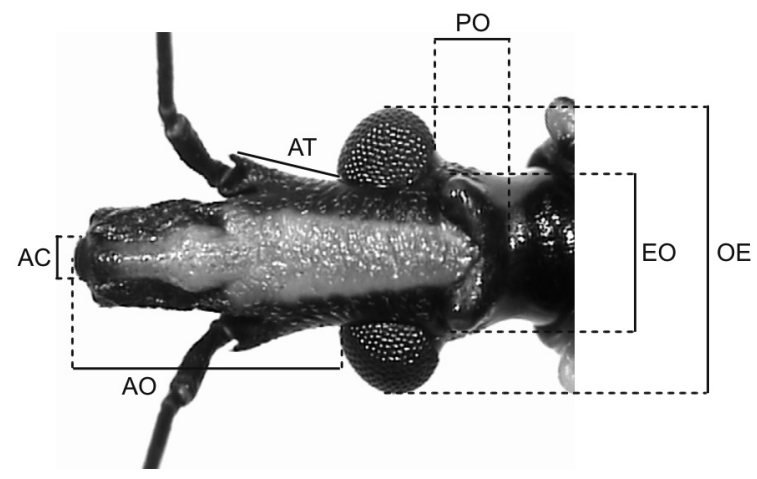

Fig. 1: morphometric measurements of the head of an adult Triatoma vitticeps. AC: width of anteclypeus; AT: length of antennal tubercle; AO: anteocular distance; EO: external distance between ocelli; OE: external distance between eyes; PO: postocular distance excluding neck. able measurements, using the Microsoft Office Excel programme version 2003. The values were submitted to analysis of variance by Tukey's test using the Minitab release program 13.20. Multivariate analyses were performed separately for males and females. Analysis of the common principal components is a multivariate analysis method that examines the different matrices of variancecovariance. This analysis combines all the variable measurements, giving rise to new variables or factors, where the first common principal component is that related to size. Discriminant analysis was also performed to obtain the components of shape. This analysis generates independent factors formed from all the common principal components except the first. These factors are denominated discriminant functions or canonic variables. Their purpose is to discriminate the pre-established groups by the observer, based not only on their size but also on their form. Factorial maps were constructed to illustrate the possible differences of size and form between the sexes and populations. The significance values are given according to Wilks (1932). Multivariate analyses were made using the JMP 3.1 and NTSYSpc 2.0 programmes.

$R A P D$ - Legs were removed from adult insects (10 males and 10 females) and stored at $-70^{\circ} \mathrm{C}$. DNA was extracted using a leg from each insect and the Promega commercial kit (Wizard Genomic DNA Purification System) following the extraction protocol modified by Borges et al. (2000). The concentration and degree of purity of DNA extracted was estimated by spectrophotometric reading (GeneQuant, Amersham Pharmacia Biotech) to 260 and $280 \mathrm{~nm}$ from $60 \mu \mathrm{l}$ of the DNA solution, this being rejected later. The four primers used - 3302 (5' CTGATGCTAC 3'), 3303 (5' TCACGATGCA 3'), 3304(5' GCACTGTCA 3') and 3307 (5' AGTGCTACGT 3') were selected based on their reproductive profiles and the great variability of displayed bands. The amplification products were visualized in $8 \%$ polyacrylamide mini gels stained with silver. A negative control was included in each mini-gel. Due to the homogeneity of the RAPD profiles presented among the groups, in the final analyses only seven randomly selected individuals of each sex and habitat and Rhodnius neglectus DNA (outgroup) were included in all the analysis.

The analysis of RAPD data was carried out according to the following assumptions: 1: the RAPD alleles segregate in Mendelian proportions; 2: bands of the same size are homologous; 3 : different loci segregate independently; and 4: populations analysed are in Hardy-Weinberg equilibrium (Apostol et al. 1996). Thus, the profile obtained by RAPD-PCR was used to construct binary matrices based on the presence or absence of bands. These matrices were used to calculate the allelic frequencies (Apostol et al. 1996), allowing the following parameters of genetic diversity to be calculated: effective number of alleles $(\mathrm{Ne})$, number of polymorphic loci (S), proportion of polymorphic loci $(\mathrm{k})$, and mean heterozygosity $(\mathrm{H})$. All these parameters were calculated using the PopGene programme, version 1.32. Genetic differentiation among the populations was evaluated by incrossing index $\left(G_{s t}\right)$, which is regarded as an extension of Wright's $\mathrm{F}_{\mathrm{st}}$ to the 
case of multiple alleles, since it is a weighted mean of $\mathrm{F}_{\text {st }}$ over all extant alleles (Takahata \& Nei 1984). The genetic distances (D) was also used to evaluate genetic differentiation among samples from distinct habitats (Nei 1978). All these parameters were also calculated using the PopGene programme, version 1.32 .

A UPGMA dendrogram (unweighted pair-group method with arithmetic average) was constructed from the genetic distance values using the Mega program v. 2.1 (Kumar et al. 2004) to visualize the relationships among the samples studied. Binary matrices were also used to obtain the similarity coefficient of Dice (1945) and construct a UPGMA dendrogram using the NTSYSpc 2.0 program.

Isoenzymes - The wing muscles of 12 insects (6 males and 6 females) from each habitat were extracted by means of a section in the pronotal region, and ground in $100 \mu \mathrm{l}$ of enzymatic stabilizer for cryopreservation (Dujardin \& Tibayrenc 1985). Ten enzymes were studied: malate dehydrogenase (MDH E.C.1.1.1.37), malic enzyme (ME E.C.1.1.1.40), glucose phosphate isomerase (GPI E.C.5.3.1.9.), glucose 6 phosphate dehydrogenase (G6PGD E.C.1.1.1.49), 6 phosphoglyconate dehydrogenase (6PGD E.C.1.1.1.44), isocitrate dehydrogenase (ICD E.C.1.1.1.42), $\alpha$-glycerophosphate dehydrogenase ( $\alpha$-GPD E.C.1.1.1.8), peptidase 2 (PEP-2 E.C.3.4.13), phosphoglycomutase (PGM E.C.2.7.5.1) and alanine aminotransferase (ALAT E.C.2.6.1.2). The electrophoretic runs were processed in amide gels at $4{ }^{\circ} \mathrm{C}$ (Romanha 1982, Dujardin \& Tibayrenc 1985), the reaction buffers, developing solutions, voltages and running time were specific for each enzyme (Abderrazak et al. 1993).

\section{RESULTS}

Morphometry - The Guillaumin profile clearly shows the presence of significant sexual dimorphism $(\mathrm{p}<0.05)$ in the three samples of $T$. vitticeps studied. The intradomiciliary females were larger than the others and the sylvatic males the smallest. With respect to common main component analysis, the first main component (which corresponds to the size analysis) contributed $67.5 \%$ for the males and $71.3 \%$ for the females and no significant differences were revealed using the Tukey-Kramer test $(p>0.05)$. The factorial map constructed from canonical components for T. vitticeps samples (Fig. 2), did not discriminate from distinct habitats (Wilks Lambda $\mathrm{p}>0.05$ ).

$R A P D$ - 42 RAPD loci were displayed for the T. vitticeps samples (Fig. 3): 12 were obtained by primer 3302, 11 by primers 3303 and 3304, and eight by $3307 ; 22$ out of the 42 loci analysed were polymorphic $(\mathrm{k}=52.38 \%)$. Variability was very low; samples from the peridomicile were the most polymorphic $(\mathrm{S}=19 / \mathrm{k}=45.24 \%)$, while the intradomicile were the lowest variable $(\mathrm{S}=15 / \mathrm{k}=37.71 \%)$. The $\mathrm{Ne}$, as well as the $\mathrm{H}$ presented low values in all the populations studied (Table). Both the $\mathrm{G}_{\mathrm{st}}$ and genetic distances were very low, ranging from 0.073-0.099 and 0.02-0.04, respectively (Table). The dendrogram obtained from Dice's similarity coefficient (Fig. 4) shows a unique group formed by all T. vitticeps individuals, despite their habitat and sex (all indi- viduals lying very far from the phenon line). Approximately $87 \%$ similarity was detected among samples and there was no evidence of separation between the populations, as confirmed by the low values of genetic distance (Fig 5).

Isoenzymes - No polymorphism was found in the electrophoretic mobility of the isoenzymes of T. vitticeps. The enzymes G6PD, PGM, ME, 6PGD, ALAT and ICD presented one band while GPI, PEP-2 and MDH present two, and $\alpha$-GPD three.
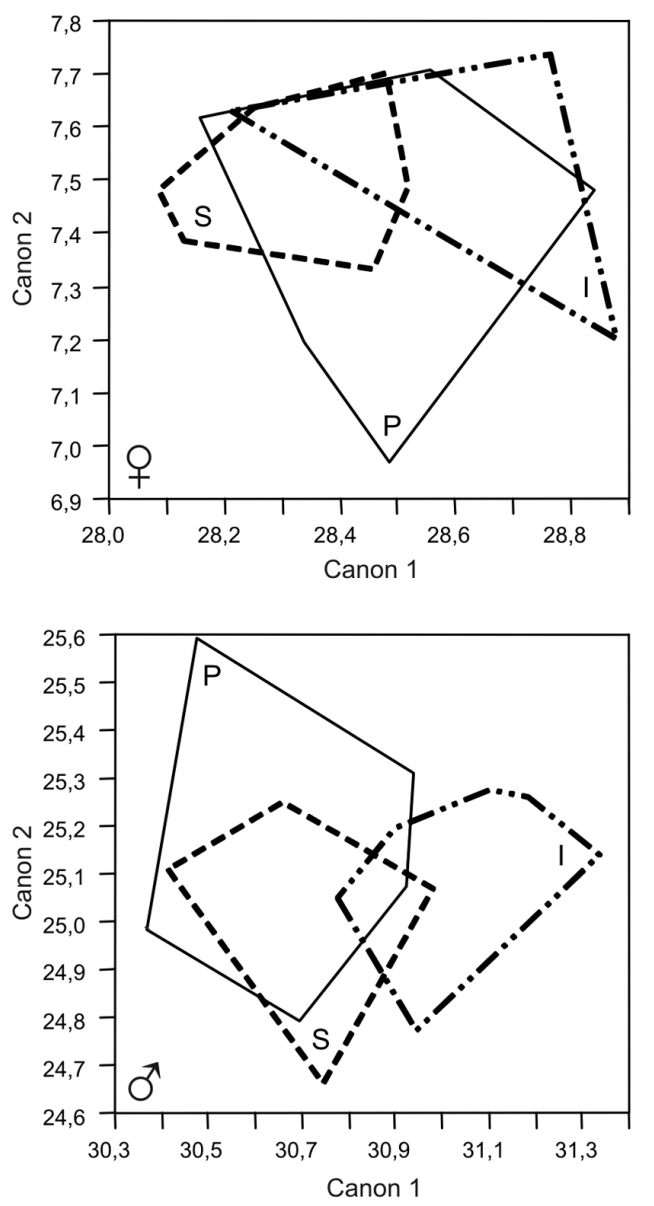

Fig. 2: factorial maps showing relationships between Triatoma vitticeps samples for discriminant analysis of shape. The polygons include all individuals sampled from each habitat: I: intradomicile; P: peridomicile; S: sylvatic.

\section{TABLE}

Genetic structure of samples analyzed comparing pairwise and separated with regard to habitat of origin: intradomicile, peridomicile and sylvatic

\begin{tabular}{lccccc}
\hline Samples & $\mathrm{Ne}$ & $\mathrm{H}$ & $\mathrm{G}_{\text {st }}$ & $\mathrm{Nm}$ & $\mathrm{D}$ \\
\hline Intra/Peri & 1.27 & 0.15 & 0.099 & 4.56 & 0.04 \\
Intra/Silv & 1.23 & 0.14 & 0.073 & 6.37 & 0.04 \\
Peri/Silv & 1.22 & 0.13 & 0.093 & 4.9 & 0.02
\end{tabular}

$\mathrm{Ne}$ : effective number of alleles; Hs: heterozygosity; Ht: total heterozygosity; Gst: index of incrossing; Nm: effective number of migrants per generation; D: genetic distance. 


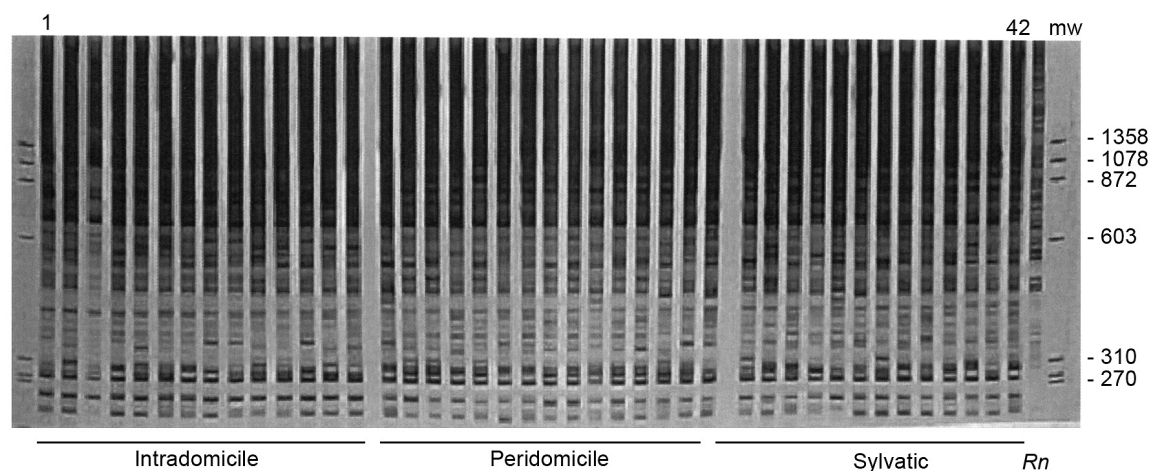

Fig. 3: random amplified polymorphism of DNA profiles of Triatoma vitticeps using primer 3304. mw: pattern of molecular weight; bp: base pairs; Lanes 1-7: intradomiciliary females; 8-14: intradomiciliary males; 15-21: peridomiciliary females; 22-28 peridomiciliary males; 29-35: sylvatic females; 36-42: sylvatic males; Rn: R. neglectus. Lane numbers shown above gel.

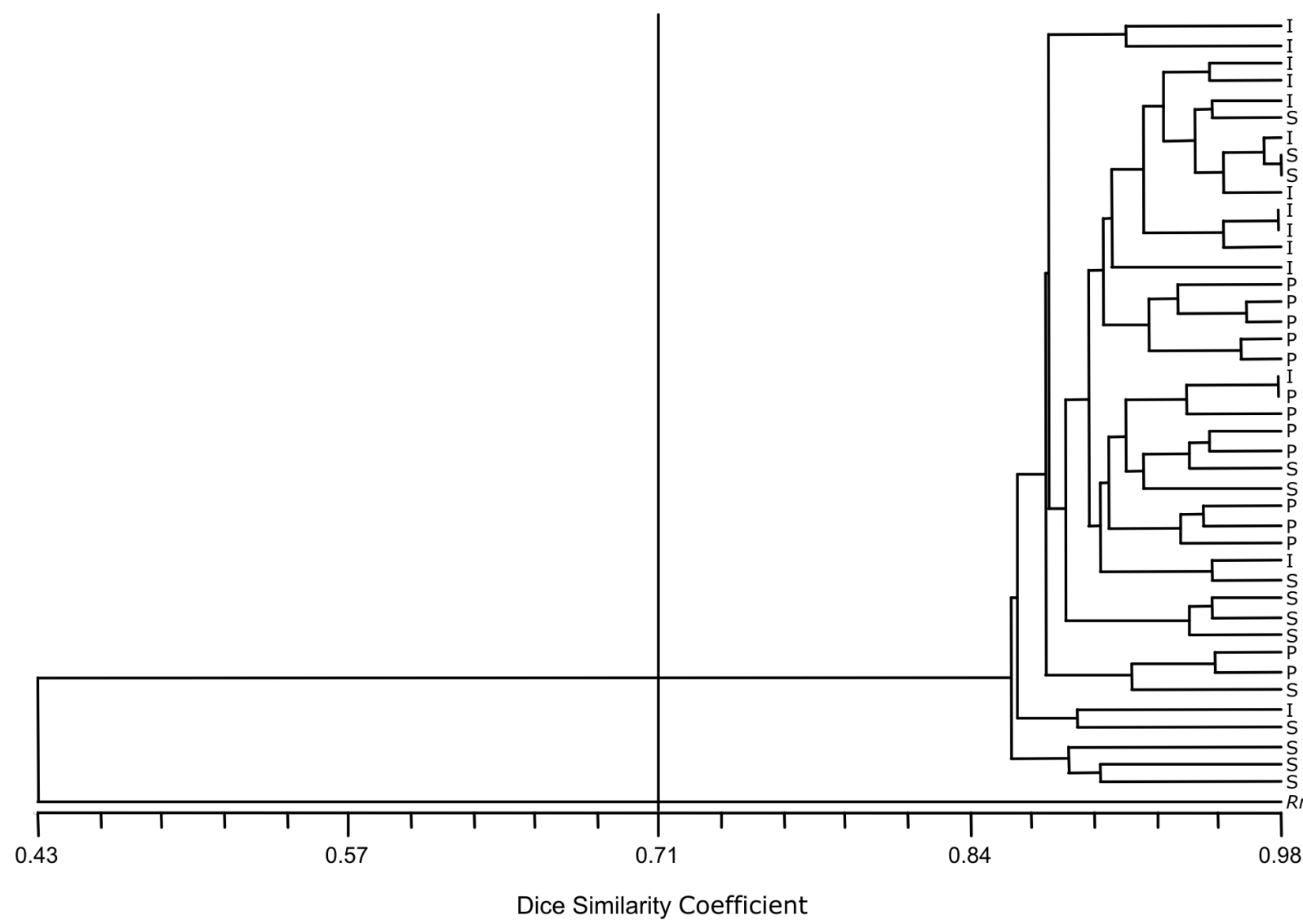

Fig. 4: dendrogram constructed from Dice similarity coefficient obtained from random amplified polymorphism of DNA electrophoretic profiles of Triatoma vitticeps from Itanhomi by using primers 3302, 3303, 3304 and 3307. Vertical bar corresponds to phenon line. Codes on the right indicate the habitat where each individual was captured: I: intradomicile; P: peridomicile; S: sylvatic.

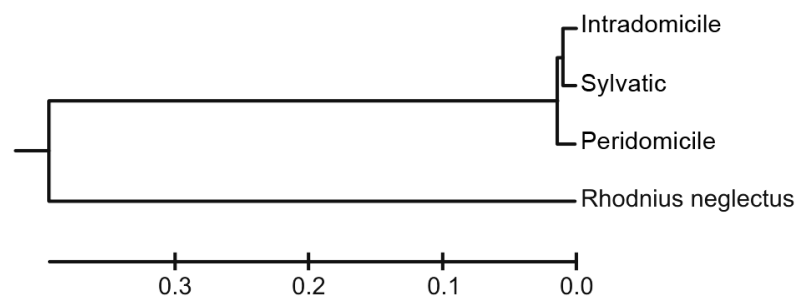

Fig. 5: dendrogram constructed from genetic distances obtained for random amplified polymorphism of DNA electrophoretic profiles of Triatoma vitticeps from Itanhomi by using primers 3302, 3303, 3304, and 3307.

\section{DISCUSSION}

Morphometric analysis of the head is a technique that is commonly used in triatomine population studies (Dujardin et al. 1998, Soares et al. 1999, Borges et al. 2000, Jaramillo et al. 2002, Barbosa 2004, Borges et al. 2005). In univariate analysis, the Guillaumin profile allows samples to be compared for each character separately, providing information on the size and symmetry of one group in relation to others. In the present study this analysis revealed clear sexual dimorphism: females from each 
habitat being significantly larger than males. According to Dujardin et al. (1998) loss of sexual dimorphism by reduction in female size probably results from competition for food and greater energy expenditure for oviposition, and may be used as a marker for domiciliation. The fact that the present results showed a high sexual dimorphism level may indicate, once more, a low capacity of intradomiciliary colonization in T. vitticeps. However, in comparisons between individuals of the same sex and different habitats, none of the differences in size (ACPC) or shape (canonic components) was significant.

RAPD markers have been used in various studies of triatomine population genetics (Garcia et al. 1998, Jaramillo et al. 2001, Dorn et al. 2003, Calderón et al. 2004, Borges et al. 2005, Barbosa et al 2006). Using analysis of the similarity presented by RAPD profiles, Borges et al. (2005) observed a clear separation of Triatoma brasiliensis from the Brazilian state of Ceará into three samples from sylvatic, peridomiciliary and domiciliary habitats. The finding of some specimens with profiles corresponding to another habitat, such as peridomiciliary insects indoors and sylvatic insects in the peridomicile, demonstrated the exchange of triatomines between these habitats, suggesting that the peridomiciliary population acts as a bridge, receiving genes from the sylvatic individuals and passing them on to the domestic ones.

In this study, the UPGMA dendrogram obtained from profiles generated by RAPD showed a unique group including the insects captured in the three environments, randomly distributed without any separation by sex or environment, based on the low genetic distance values found. Formation of a homogeneous group was not evident even in the peridomicile, where colonization occurred, reinforcing the idea of interchange of insects between environments. In Guatemala, Dorn et al. (2003) and Calderón et al. (2004) observed high levels of genetic variability in Triatoma dimidiata populations, with $\mathrm{k}$ values of $79.3-100 \%$, and $\mathrm{H}$ of $0.283-0.352$. In the present study, we observed much lower values for $\mathrm{k}=$ $37.71-45.24 \%$ and $\mathrm{H}=0.13-0.15$, demonstrating a small genetic difference between insects from different habitats. These results coincide with the environmental conditions of Itanhomi, characterized by proximity of the three habitats (intra, peridomestic and sylvatic), absence of domestic bug colonies and reports by the local population of daily household invasions by triatomines.

Isoenzymes may be important population markers for some species of triatomines. Dujardin and Tibayrenc (1985) found three patterns for the enzyme PGM in Triatoma infestans, allowing sylvatic and domiciliary populations to be characterized. Pires (1995), comparing populations of T. infestans from Bolivia and Brazil, found two patterns for this enzyme among insects from Cochabamba and only one for the Brazilian populations, supporting the hypothesis of genetic simplification as a consequence of passive dispersal in this species, resulting in the selection of extremely homogeneous individuals. Also using isoenzymes, Barbosa et al. (2003) proposed that the hypothetical centre of origin of Panstrongylus megistus be expanded to include Minas Gerais and Bahia, based on the assumption that triatomines should present the great- est variability of habitats. However, in other triatomine population studies based on RAPD and morphometrics, the isoenzymes did not show differences (Dujardin et al. 1987, 1997, 1998, Soares et al. 1999, Borges et al. 2000). In the present study, this marker showed itself to be extremely homogeneous for the three samples studied, in concordance with previous findings.

This is the first report of a $T$. vitticeps population dynamics study involving taxonomic tools. The similarity of RAPD patterns, absence of differences in size and form, clear sexual dimorphism by morphometry and isoenzymatic monomorphism among the individuals of the three habitats together suggest intense movement of the triatomines between them. This species appears unable to establish intradomiciliary colonies, even though it is frequently captured indoors in Itanhomi with high infection rate.

The population dynamics between different environments defines the natural history of the triatomines and the Chagas disease. According to classic epidemiological patterns, artificial environments are usually colonized by wild triatomines (Forattini 1980). The concept of colonization (presence of immature nymphs) is directly related to the ability of different species to adapt to artificial environments, forming close associations with domestic and peridomestic animals as well as to humans (Pereira et al. 2006). In the case of $T$. vitticeps, we are facing a species with unique characteristics, whose contact with man does not seem to be related to the occurrence of intradomiciliary colonies but rather to repeated invasions of dwellings from surrounding areas. Apparently this contact does not result in transmission of $T$. cruzi to man, since the prevalence of Chagas disease in Itanhomi is very low (Camargo et al. 1984). It may be a consequence of the prolonged interval between feeding and defecation in this species (Diotaiuti et al. 1987, Gonçalves et al. 1988, Santos et al. 2006). However one cannot ignore the incursion of this triatomine in houses and thus the importance of epidemiological vigilance, in anticipation of possible behavioural changes in T. vitticeps that could increase the risk of $T$. cruzi transmission to the human population.

\section{ACKNOWLEDGEMENTS}

To Dr Nicolas Jaramillo for the comments on the morphometric analysis and to Bruce Alexander for translating the manuscript to English. To Dr Ricardo Lourenço-de-Oliveira for the revision of the text. To the staff of Fundação Nacional de Saúde for helping in collecting the insects, especially Mrs Aloísio Carlos Dias and Clévio Moreira da Silva.

\section{REFERENCES}

Abderrazak SB, Guerrini F, Mathieu-Daudé F, Truc P, Neubauer K, Lewika K, Barnabé C, Tibayrenc M 1993. Isoensyme eletroforesis for parasite caracterization. In E Jonh (ed.), Methods in Molecular Biology, Protocols in Molecular Pasasitology, Hyde Co. Humana Press, Totowa, p. 361-381.

Apostol BL, Black IV WC, Reiter P, Miller BR 1996. Population genetics with RAPD-PCR markers: the breeding structure of Aedes aegypti in Puerto Rico. Heredity 76: 325-334.

Barbosa SE 2004. Biossistemática e Biogeografia de populações de Panstrongylus megistus (Burmeister, 1835) no Brasil, PhD Thesis, 
Universidade Federal de Minas Gerais, Belo Horizonte, 147pp.

Barbosa SE, Belisário CJ, Souza RCM, Paula ASP, Linardi PM, Romanha AJ, Diotaiuti L 2006. Biogeography of Brazilian populations of Panstrongylus megistus (Hemiptera, Reduviidae, Triatominae) based on molecular marker and paleo-vegetational data. Acta Trop 99: 144-154.

Barbosa SE, Dujardin JP, Soares RPP, Pires HHR, Margonari C, Romanha AJ, Panzera F, Linardi PM, Duque-de-Melo M, Pimenta PFP, Pereira MH, Diotaiuti L 2003. Interpopulation variability among Panstrongylus megistus (Hemiptera: Reduviidae) from Brazil. J Med Entomol 40: 144-420.

Barros G, Mayrink W, Salgado AA, Barros RC, Sessa PA 1975. Contribuição para o conhecimento da doença de Chagas autóctone no estado do Espírito Santo. Rev Inst Med Trop São Paulo 17: 319-329.

Bérenger JM, Blanchet D 2007. A new species of the genus Panstrongylus from French Guiana (Heteroptera; Reduviidae; Triatominae). Mem Inst Oswaldo Cruz 102: 733-736.

Borges EC, Dujardin JP, Romanha AJ, Diotaiuti L 2000. Genetic variability of Triatoma brasiliensis (Hemiptera:Reduviidae) populations. J Med Entomol 37: 872-877.

Borges EC, Dujardin JP, Schofield CJ, Romanha AJ, Diotaiuti L 2005. Dynamics between sylvatic, peridomestic and domestic populations of Triatoma brasiliensis (Hemiptera:Reduviidae) in Ceará State, Northeastern Brazil. Acta Trop 93: 119-126.

Calderón CI, Dorn PL, Melgar S, Chávez JJ, Rodas A, Rosales R, Monroy CM 2004. A preliminary assessment of genetic differentiation of Triatoma dimidiata (Hemiptera: Reduviidae) in Guatemala by Random Amplification of Polymorphic DNAPolymerase Chain Reaction. J Med Entomo 41: 882-887.

Camargo ME, Silva GR, Castilho EA, Silveira AC 1984. Inquérito sorológico da prevalência da infecção chagásica no Brasil, 1975/1980. Rev Inst Med Trop São Paulo 26: 192-204.

Costa JM, Argolo AM, Felix M 2006. Redescription of Triatoma melanica Neiva \& Lent, 1941, new status (Hemiptera: Reduviidae: Triatominae). Zootaxa 1385: 47-52

Costa JM, Felix M 2007. Triatoma juazeirensis sp. nov. from the state of Bahia, Northeastern Brazil (Hemiptera:Reduviidae: Triatominae). Mem Inst Oswaldo Cruz 102: 87-90.

Costa JM, Freitas-Sibajev MGR, Marchon-Silva V, Pires MQ, Pacheco RS 1997 Isoenzymes detect variation in populations of Triatoma brasiliensis (Hemiptera: Reduviidae: Triatominae). Mem Inst Oswaldo Cruz 92: 459-464.

Dias JCP, Feitosa VR, Ferras Filho A, Rodrigues VLC, Alencar SA, Sessa PA 1989. Fonte alimentar e potencial vetorial do Triatoma vitticeps com relação a doença de Chagas Humana no estado do Espírito Santo, Brasil (Hemiptera, Reduviidae). Mem Inst Oswaldo Cruz 84: 165-173.

Dice LR 1945. Measures of the amount of ecological association between species. Ecology 26: 297-302.

Diotaiuti L, Bronfen E, Perillo MM, Machado GBM, Loiola CF 1987. Aspectos do comportamento biológico do Triatoma vitticeps na transmissão da doença de Chagas. Rev Soc Bras Med Trop 20: 87.

Dorn PL, Melgar S, Rouzier V, Gutierrez A, Combe C, Rosales R, Rodas A, Kott S, Salvia D, Monroy CM 2003. The Chagas vector, Triatoma dimidiata (Hemiptera: Reduviidae), is panmitic within and among adjacent villages in Guatemala. J Med Entomol 40: 436-440.

Dujardin JP, Bermudez H, Casini C, Schofield CJ, Tibayrenc M 1997. Metric differences between sylvatic and domestic Triatoma infestans (Hemiptera: Reduviidae) in Bolivia. J Med Entomol 34: 544-551.
Dujardin JP, Schofield CJ, Tibayrenc M 1998. Population structure of Andrean Triatoma infestans: allozyme frequencies and their epidemiological revelance. Med Vet Entomol 12: 20-29.

Dujardin JP, Tibayrenc M 1985. Etudes isoenzymatiques du vecteur principal de la maladie de Chagas: Triatoma infestans (Hemiptera: Reduviidae). Ann Soc Belg Med Trop 65 (Suppl. 1): 165-169.

Dujardin JP, Tibayrenc M, Venegas E, Maldonado L, Desjeux P, Ayala FJ 1987. Isozyme evidence of lack of speciation between wild and domestic Triatoma infestans (Heteroptera: Reduviidae) in Bolivia. J Med Entomol 24: 40-45.

Ferreira E, Souza PSA, Filho MF, Rocha I 1986. Nota sobre a distribuição geográfica do Triatoma vitticeps Stål, 1859 (Hemiptera, Reduviidae) no estado do Rio de Janeiro, Brasil. Rev Bras Mal D Trop 38: 11-14.

Forattini OP 1980. Biogeografia, origem e distribuição da domiciliação de triatomíneos no Brasil. Rev Saúde Públ 14: 265-299.

Galvão C, Ângulo VM 2006. Belminus corredori, a new species of Bolboderini (Hemiptera: Reduviidae: Triatominae) from Santander, Colômbia. Zootaxa 1241: 61-68.

Galvão C, Carcavallo R, Rocha DS, Jubert J 2003. A checklist of the currente valid species of the subfamily Triatominae Jeannel, 1919 (Hemíptera, Reduviidae) and their geografical distribution, with nomenclatural and taxonomic notes. Zootaxa 202: 1-36.

Garcia AL, Carrasco HJ, Schofield CJ, Stothard JR, Frame IA, Valente SAS, Miles MA 1998. Random Amplification of Polymorphic DNA as a tool for taxonomic studies of triatomine bugs (Hemiptera: Reduviidae). J Med Entomol 35: 38-45.

Gonçalves TCM, Oliveira E, Dias LS, Almeida MD, Nogueira WO, Pires FDA 1998. An investigation on the ecology of Triatoma vitticeps (Stål, 1859) and its possible role in the transmission of Trypanosoma cruzi, in the locality of Triunfo, Santa Maria Madalena municipal district, state of Rio de Janeiro, Brazil. Mem Inst Oswaldo Cruz 93: 711-717.

Gonçalves TCM, Victório VMN, Jurberg J, Cunha V 1988. Biologia de Triatoma vitticeps (Stal, 1859) em condições de laboratório (Hemiptera:Triatominae). I. Ciclo Evolutivo. Mem Inst Oswaldo Cruz 83: 519-523.

Guillaumin M 1972. Étude biometric des populations naturalles de $P$. carlivae Rbr et $P$. ciasii Rbr (Lep. Hesperidae). I. Estimation du taux de chevauchement des distributions statistiques de deux populations en relation avec la notion de distance taxonomique. Arch Zool Exp Gen 115: 505-548.

Jaramilho C, Montana MF, Castro LR, Vallejo GA, Guhl F 2001. Differentiation and genetic analysis of Rhodnius prolixus and Rhodnius colombiensis by rDNA and RAPD amplification. Mem Inst Oswaldo Cruz 96: 1043-1048.

Jaramillo NO, Castillo D, Wolf ME 2002. Geometric morphometric differences between Panstrongylus geniculatus from field and laboratory. Mem Inst Oswaldo Cruz 97: 667-673.

Kumar S, Tamura K, Nei M 2004. MEGA3: Integrated software for Molecular Evolutionary Genetics Analysis and sequence alignment. Brief Bioinform 5: 150-163.

Martinez E, Chávez T, Sossa D, Aranda R, Vargas B, Vidaurre P 2007. Triatoma boliviana sp. n. de los valles subandinos de La Paz, Bolivia (Hemiptera: Reduviidae: Triatominae), similar a Triatoma nigromaculata Stål, 1859. Bol Inst Invest Salud Desar 3: 1-11.

Nei M 1978. Estimation of average heterozygosity and genetic distance from a small number of individuals. Genetics 89: 583-590.

Noireau F, Flores R, Gutierrez T, Vargas K 1999. Triatomi em Bolívia: Importancia actual de los vetores. La Enfermedad de Chagas en 
Bolivia. Conociementos científicos al início del Programa de Control (1998-2002), Ministerio de Salud y Prevision Social, La Paz, Bolívia, 259 pp.

Pereira MH, Gontijo NF, Guarneri AA, Sant'Anna MRV, Diotaiuti L 2006. Competitive displacemente in Triatominae: the Triatoma infestans success. Trends Parasitol 22: 516-520.

Pinto AFS, Santos UM, Murad V, Lima FEP, Zaganelli FL, Almeida AZ 1969. Doença de Chagas no Estado do Espírito Santo. V Primeiro caso de Chagas diagnosticado no Município de Alfredo Chaves, E.S. Rev Soc Bras Med Tropical 3: 53.

Pinto AFS, Vieira NER, Milanez MC, Lima Pereira FE, Sessa PA 1986. Doença de Chagas autóctone no Espírito Santo: relato de caso agudo em gestante com transmissão para o feto. Rev Soc Bras Med Tropical 19 (Suppl.): 78.

Pires HHR 1995. Estudos comparativos entre duas populacões distintas de Triatoma infestans (Klug, 1834), PhD Thesis, Universidade Federal de Minas Gerais, Belo Horizonte, Minas Gerais, 100pp.

Romanha AJ 1982. Heterogeneidade isoenzimática em Trypanosoma cruzi, PhD Thesis, Universidade Federal de Minas Gerais, Belo Horizonte, Minas Gerais, 110pp.

Sandoval CM, Pabón E, Jurberg J, Galvão C 2007. Belminus ferroae n.sp. from the Colombian north-east, with a key to the species of the genus (Hemiptera: Reduviidae: Triatominae). Zootaxa 1443: 55-64.

Santos CB, Ferreira AL, Leite GR, Ferreira GEM, Rodrigues AAF, Falqueto A 2005. Peridomiciliary colonies of Triatoma vitticeps (Stal, 1859) (Hemiptera, Reduviidae, Triatominae) infected with Trypanosoma cruzi in rural areas of the state of Espírito Santo, Brazil. Mem Inst Oswaldo Cruz 100: 471-473.

Santos CB, Leite GR, Sessa PA, Falqueto A 2006. Dynamics of feed- ing and defecation in Triatoma vitticeps (Stal, 1859) (Hemiptera, Reduviidae, Triatominae) and its potential in the transmission of Trypanosoma cruzi. Mem Inst Oswaldo Cruz 101: 543-546.

Santos UM, Pinto, AFS, Zaganelli, FL, Almeida, AZ, Martins A, Carancho PV, Vieira HJ 1969a. Doença de Chagas no Estado do Espírito Santo. II - Inquérito sorológico. Rev Soc Bras Med Trop 3: 51.

Santos UM, Pinto, AFS, Zaganelli FL, Almeida AZ, Martins A, Carancho PV, Vieira HJ 1969b. Doença de Chagas no Estado do Espírito Santo. III - Vetores do tripanosoma. Rev Soc Bras Med Trop 3: 51-52.

Santos UM, Pinto AFS, Zaganelli FL, Almeida AZ, Martins A, Carancho PV, Vieira HJ 1969c. Doença de Chagas no Estado do Espírito Santo. IV - primeiro caso de Chagas diagnosticado no município de Rio Novo do Sul, ES. Rev Soc Bras Med Trop 3: 52-53.

Sessa PA, Carias VDR 1986. Infecção natural de triatomíneos do Espírito Santo por Flagelados morfologicamente semelhantes ao Trypanosoma cruzi. Rev Soc Bras Med Trop 19: 99-100.

Soares RPP, Barbosa SE, Borges EC, Melo Júnior TA, Romanha AJ, Dujardin JP, Schofield CJ, Diotaiuti L 2001. Genetic studies of Psammolestes tertius (Hemíptera: Reduviidae: Triatominae) using male genital morphology, morphometry, isoenzymes, and random amplified polymorphic DNA. Biochem Genet 39: 1-13.

Soares RPP, Barbosa SE, Dujardin JP, Schofield CJ, Siqueira AM, Diotaiuti L 1999. Caracterization of Rhodnius neglectus from two regions of Brazil using isoenzymes, genitalia morphology, and morphometry. Mem Inst Oswaldo Cruz 94: 161-166.

Takahata N, Nei M 1984. $\mathrm{F}_{\mathrm{st}}$ and $\mathrm{G}_{\mathrm{st}}$ statistics in the finite island model. Genetics 107: 501-504.

Wilks SS 1932. Certain generalizations in the analysis of variance. Biometrics 24: 471. 